\title{
Acute Thoracic Syndrome in Sickle Cell Children at the Pediatrics Department of Donka National Hospital
}

\author{
M. M. Diop 1,2*, A. Barry',2, M. L. Diallo²,3, E. Camara1,2, I. K. Barry'2,3, M. A. Doukoure1, M. C. Barry ${ }^{2,4}$, \\ S. B. Diallo", , N. V. Gateu Tadjom1, H. Dia ${ }^{2,4}$, M. P. Diallo ${ }^{1,2}$ \\ ${ }^{1}$ Departement of Pediatric, Donka National Hospital, Conakry, Guinea \\ ${ }^{2}$ University Gamal Abdel Nasser of Conakry, Conakry, Guinea \\ ${ }^{3}$ Pediatric Emergency Department, Donka National Hospital, Conakry, Guinea \\ ${ }^{4}$ Ignace Deen Department of Pediatrics, Conakry, Guinea \\ Email: *diopmoustapha79@gmail.com
}

How to cite this paper: Diop, M.M., Barry, A., Diallo, M.L., Camara, E., Barry, I.K., Doukoure, M.A., Barry, M.C., Diallo, S.B., Tadjom, N.V.G., Dia, H. and Diallo, M.P. (2020) Acute Thoracic Syndrome in Sickle Cell Children at the Pediatrics Department of Donka National Hospital. Open Journal of Pediatrics, 10, 688-694.

https://doi.org/10.4236/ojped.2020.104071

Received: September 26, 2020

Accepted: December 11, 2020

Published: December 14, 2020

Copyright $\odot 2020$ by author(s) and Scientific Research Publishing Inc. This work is licensed under the Creative Commons Attribution International License (CC BY 4.0).

http://creativecommons.org/licenses/by/4.0/

\begin{abstract}
Introduction: Acute thoracic syndrome is the appearance of a new pulmonary infiltrate on radiology associated with fever, desaturation or respiratory signs. It is the second leading cause of hospitalization and the first cause of death in sickle cell patients. It is an acute pulmonary complication whose pathophysiological mechanisms are still poorly understood. This study aims to study the epidemiological, clinical, therapeutic and evolutionary aspects of Acute Chest Syndrome in children at the Pediatrics Department of Donka National Hospital. Method: This is a prospective study of descriptive type for a period of 6 months from February 19 to August 19, 2019 on patients with sickle cell disease who developed an ATS in the pediatrics department of Donka National Hospital. Epidemiological, clinical, therapeutic and evolutionary data were studied and proportionate data were calculated. Results: The frequency of ATS was $39 \%$. The mean age of our patients was 9.83 years with the extremes of 4 and 16 years. The age group from 6 to 10 years with a frequency of $66.7 \%$ was the most affected. Fever was the main clinical manifestation, followed by hepatomegaly. All our patients were homozygous SS and undergoing folic acid prophylaxis. $96 \%$ of our patients did not receive any specific vaccine. Antibiotic therapy, hyperhydration and analgesics were administered to all our patients. $96 \%$ of our patients were transfused with red blood cell concentrate. $96 \%$ of our patients were transfused with packed red blood cells. $96 \%$ of our patients were transfused with packed red blood cells and $96 \%$ of them had a favorable outcome. Conclusion: ATS is an acute complication of sickle cell disease responsible for significant mortality and morbidity in the
\end{abstract}


pediatric population. Its treatment is symptomatic and must be started early.

Emphasis must be placed on prevention to prevent or limit its occurrence.

\section{Keywords}

Sickle Cell Disease, Acute Thoracic Syndrome, Pediatrics Donka

\section{Introduction}

Sickle cell disease is an autosomal recessive genetic disease linked to a hemoglobin abnormality, characterized by the replacement of glutamic acid by valine on the $\beta$ chain [1].

It is a real public health problem in the world because of its morbidity and mortality, especially in childhood. According to the WHO, 2 to 3 million children with sickle cell disease are born in the world every year. It is the most common genetic disease and mainly affects black populations [2].

It combines chronic hemolytic anemia, susceptibility to bacterial infections, vaso-occlusive phenomena and hypercoagulability [3] [4].

Among acute complications, acute thoracic syndrome (ATS) is the second leading cause of hospitalization and the first cause of death in patients with sickle cell disease [5].

Ballas and Coll define it as the appearance of a new pulmonary infiltrate in radiology with fever, desaturation or respiratory signs [6].

It is an acute pulmonary complication whose pathophysiological mechanisms are still poorly understood [7] [8].

Given the complexity of its mechanisms of action and the difficulty in identifying a precise etiological factor in many patients, the management of ATS is non-specific and symptomatic [9].

In the United States, Castro. O et al. in a national multicenter study group found an incidence of $29 \%$. Of the 3751 patients enrolled, 1085 had an x-ray compatible with an ATS. The incidence was higher in homozygous SS and thalassemia $\beta 0$ and lower in patients with hemoglobin SC and $\beta+$ [10].

In a study conducted in 2012 by S. Bertholdt et al. Belgium on the respiratory complications of sickle cell disease, 25 patients out of 69 listed had presented one or more episodes of ATS, i.e. a prevalence of 36.23\% [11]. In Cameroon in 2017 M. Bassi Awa et al. in a study conducted in three hospitals in Yaoundé identified 102 patients, 13 of whom had developed ATS, i.e. 7.84\% [1], in their study in Senegal Diagne. I et al. found 1\% [2].

In Guinea, Hounsa. T Alfred at Donka National Hospital in his thesis work found $4.4 \%[12]$.

The aim of this study was to study the epidemiological, clinical, therapeutic and evolutionary aspects of ATS in children in the pediatrics department of the DONKA National Hospital. 


\section{Methods}

This is a prospective study of descriptive type for a period of 6 months from February 19 to August 19, 2019 carried out at Donka National Hospital.

It included all children with sickle cell disease in the pediatric ward received for ATS (Acute Chest Syndrome) presenting: fever, respiratory signs (cough, chest pain, dyspnea, rales), pulmonary infiltrate on X-ray. All children with sickle cell disease who presented with ATS during hospitalization.

A structured survey form was used to collect socio-demographic, clinical and therapeutic data from the children, which were entered and processed using EPI info 7.2 software and then presented in the form of results using Word and Excel software from the Office 2010 pack.

The anonymity and confidentiality of the information collected were preserved.

\section{Results}

Out of 64 patients with sickle cell disease seen in the pediatrics department of Donka National Hospital during our study period, we collected 25 cases of ATS, i.e. a frequency of $39 \%$. The age group of $6-10$ years was the most affected at 66.7\%; the mean age was 9.83 years with extremes of 4 years and 16 years. Male sex predominates, with $64 \%$ of cases with a sex ratio of 1.77 . The average age was 9.83 with extremes of 4 and 16 years. Household mothers were the most represented in $56 \%$ of cases, while fathers who were civil servants were the most represented in $28 \%$ of cases. Socio-demographic characteristics are shown in Table 1.

Table 1. Distribution of patients by socio-demographic characteristics.

\begin{tabular}{cccc}
\hline Sociodemographic Characteristics & & Staff & Percentage \\
\hline Sex & Male & 16 & 64 \\
& Female & 9 & 36 \\
\hline Age range (years) & {$[1-5]$} & 2 & 8 \\
& {$[6-10]$} & 16 & 64 \\
& {$[11-16]$} & 7 & 28 \\
& Housewife & 14 & 56 \\
\hline Mother's occupation & Merchant & 6 & 24 \\
& Official & 2 & 8 \\
& Others & 3 & 12 \\
& Worker & 2 & 8 \\
& Merchant & 6 & 24 \\
\hline Father's profession & Official & 7 & 28 \\
& Cultivator & 1 & 36 \\
\hline & Others & 9 & 4 \\
\hline
\end{tabular}


Out of 25 patients who developed Acute Chest Syndrome, 24 had not been vaccinated, or $96 \%$; only 1 case (4\%) had received the specific vaccines (Typhim vi, Pneumo 23, and Meningo) (Table 2). Fever was the main clinical manifestation encountered during our study with a frequency of $72 \%$ followed by hepatomegaly $68 \%$, cough and chest pain had $64 \%$ respectively. Rarer manifestations were headache $8 \%$ and jaundice $4 \%$ (Table 3 ).

On examination, we found crackling and snoring rales that were $52 \%$ and $8 \%$ respectively (Table 4). During our study, $72 \%$ of the patients had hemoglobin levels between 6 and $10 \mathrm{~g} / \mathrm{dl}$ and only 28\% (7/25) had hemoglobin levels below 6 g/dl (Table 5).

The average length of stay of patients in our department was 5.28 and the 5 to 7 day period was the most represented with $72 \%$ of the cases (Table 6).

All of our patients were on folic acid prophylaxis and were treated with analgesics, third generation cephalosporin and hyperhydration.

The most commonly used analgesic class was Tier I and Tier II. $96 \%$ of our patients received a blood transfusion of packed red blood cells (Table 7). We noted a favorable evolution in 24 cases, i.e. 96\%. However, we recorded one (1) or $4 \%$ deaths (Table 8 ).

Table 2. Frequency of specific vaccines received in the pediatrics department during our study period.

\begin{tabular}{ccc}
\hline Vaccines & Staff & Percentages \\
\hline Not vaccinated & 24 & 96 \\
Meningo AC & 1 & 4 \\
Pneumo 23 & 1 & 4 \\
Typhim VI & 1 & 4 \\
\hline
\end{tabular}

Table 3. Frequency of specific vaccines received in the Department of Pediatrics during our study period.

\begin{tabular}{ccc}
\hline Clinical events & Staff & Percentages \\
\hline Fever & 18 & 72 \\
Hepatomegaly & 17 & 68 \\
Cough & 16 & 64 \\
Chest pain & 16 & 64 \\
Splenomegaly & & 40 \\
Osteoarticular pain & 10 & 32 \\
Breathing difficulty & 8 & 8 \\
Others & 2 & 8 \\
Headache & 2 & 4 \\
Icter & 1 & \\
\hline
\end{tabular}


Table 4. Frequency of auscultatory signs of the 25 sickle cell children who developed APS in the pediatric ward during our study period.

\begin{tabular}{ccc}
\hline Auscultatory signs & Staff & Percentages \\
\hline Sizzling & 13 & 52 \\
Snoring & 2 & 8 \\
Sibilants & 1 & 4 \\
Vesicular murmur & 12 & 48 \\
\hline
\end{tabular}

Table 5. Distribution of the 25 sickle cell disease children who developed ATS in the pediatric ward during our study period by hemoglobin level.

\begin{tabular}{ccc}
\hline Hemoglobin level g/l & Staff & Percentages \\
\hline$<6$ & 7 & 28 \\
$6-10$ & 18 & 72 \\
TOTAL & 25 & 100
\end{tabular}

Table 6. Distribution of the 25 sickle cell disease children who developed APS in the pediatric ward during our study period according to length of stay.

\begin{tabular}{ccc}
\hline Length of stay/days & Staff & Percentages \\
\hline$<5$ & 5 & 20 \\
$5-7$ & 18 & 72 \\
$>7$ & 2 & 8 \\
TOTAL & 25 & 100 \\
\hline
\end{tabular}

Table 7. Frequency of treatment received by the 25 children with sickle cell disease who developed APS in the pediatric ward during our study period.

\begin{tabular}{cccc}
\hline Class of molecules & Molecules & Staff & Percentages \\
\hline Antibiotics & C3G & 25 & 100 \\
& Gentamycine & 2 & 8 \\
Analgesics & Paracetamol & 18 & 72 \\
And/or & Tramadol & 9 & 36 \\
AINS & Niflumic acid & 1 & 4 \\
Supplement & Folic Acid & 25 & 100 \\
Transfusion & Globular concentrate & 24 & 96 \\
Corticoids & Déxaméthasone & 2 & 8 \\
\hline
\end{tabular}

Table 8. Distribution of the 25 sickle cell disease children who developed ATS in the pediatrics department during our study period according to evolution.

\begin{tabular}{ccc}
\hline Evolution & Staff & Percentage \\
\hline Favorable & 24 & 96 \\
Death & 1 & 4 \\
TOTAL & 25 & 100 \\
\hline
\end{tabular}




\section{Discussion}

Acute Chest Syndrome was collected in 39\% (25/64) of the sickle cell patients seen in the Pediatrics Department of Donka National Hospital during our study period. This result is significantly higher than that obtained by M. Bassi et al. in Cameroon in 2017, who found a frequency of $10.92 \%$ in their study [1]. This high frequency in our series could be explained by the size of our sample on the one hand but also by the reputation of our service in the management of sickle cell disease on the other hand. Most of the children were male with $64 \%$ and a sex ratio of 1.17. Our result is identical to that of S. Berthold et al.

Who found male predominance but contrary to J. R. Mabiala et al. who found female predominance with a frequency of $56.8 \%$ [13]. The mean age was 9.83 years, and the age group most affected by APS was children aged 6 to 10 (66.7\%), with extremes of 4 and 16. This result is comparable to that of M. Bassi et al. and $\mathrm{J}$ R Mabiala et al. who found a predominance in the 5 to 15 age group [1] [13].

Only $4 \%$ of our patients had received the specific vaccines (thyphim VI, Pneumo 23 and Meningo). This low rate of specific vaccines is explained not only by the parents' lack of information about these vaccines, but also by their high cost.

Fever was the main clinical manifestation in our study with a frequency of $72 \%$ followed by hepatomegaly in $68 \%$ of cases. Vinschinsky et al. in the United States found fever to be the main clinical manifestation. This can be explained by the infections that are common in tropical areas [5].

$72 \%$ of our patients had hemoglobin levels between 6 and $10 \mathrm{~g} / \mathrm{dl}$. This level is slightly higher in a study in Belgium [12]. Our results are identical to those reported in the literature and could be explained by the chronic hemolytic anemia suffered by sickle cell patients.

The average length of hospitalization was 5.28 days with extremes of 2 and 10 days. The most commonly used class of analgesics was Tier I and Tier II with a small proportion. Tier III analgesics have not been used in our series because of their official unavailability in our country. $96 \%$ of our patients received a transfusion, which could be explained by the fact that the majority of our patients were decompensating for their anemia. The evolution was favorable in $96 \%$ of the cases, however we noted one case of death, i.e. $4 \%$. In this work, Hounsa $\mathrm{T}$ attributed 4 deaths to ATS and anaemia [12] while M. Bassi et al. in Cameroon had recorded 2 deaths from ATS [1].

\section{Conclusion}

ATS (Acute Chest Syndrome) is a serious complication of sickle cell disease. It is one of the most common complications among sickle cell patients in the Pediatrics Department of Donka National Hospital. Community screening would be an effective way to prevent or reduce complications related to sickle cell disease, especially acute chest syndrome. 


\section{Conflicts of Interest}

The authors declare no conflicts of interest regarding the publication of this paper.

\section{References}

[1] Awa, H.M., Dongmo, F., Um, S.N., Fonkwo, V.M., Yanda, A.A., Nlend, A.E.N., et al. (2017) Aspects Épidémiologiques, Cliniques et Thérapeutiques des Crises Vaso-Occlusives chez les Enfants Drépanocytaires en Milieu Hospitalier à Yaoundé. Health Sciences and Diseases, 18, 90.

[2] I. DIAGNE: La drépanocytose, UFR-2S Université Gaston Berger, Saint Louis Sénégal, Dakar. BP: 234. http://www.ugb.sn/

[3] Labie, D. and Elion, J. (1996) Modulation polygénique des maladies monogéniques. Med Sci (Paris), 12, 341-349. https://doi.org/10.4267/10608/737

[4] PNDS_SyndromesDrepanocytairesMajeursAdulteEnfant.pdf n.d.

[5] Vichinsky, E.P. (1997) Acute Chest Syndrome in Sickle Cell Disease: Clinical Presentation and Course. Blood, 89, 1787-1792. http://www.bloodjournal.org/content/89/5/1787/tab-figures-only?sso-checked=true

[6] Ballas, S.K., et al. (2010) Definitions of the Phenotypic Manifestations of Sickle Cell Disease. American Journal of Hematology, 85, 6-13. https://www.ncbi.nlm.nih.gov/pubmed/19902523

[7] Netgen (2006) Drépanocytose: Syndromes thoracique aigu et de détresse respiratoire. De la pathophysiologie au traitement. Rev Med Suisse. https://www.revmed.ch/RMS/2006/RMS-91/31851

[8] Maître, B., Mekontso-Dessap, A., Habibi, A., Bachir, D., Parent, F., Godeau, B., et al. (2011) Complications pulmonaires des syndromes drépanocytaires majeurs chez l'adulte. Revue Des Maladies Respiratoires, 28, 129-137. https://doi.org/10.1016/j.rmr.2010.08.013

[9] Vichinsky, E.P., Neumayr, L.D., Earles, A.N., Williams, R., Lennette, E.T., Dean, D., et al. (2000) Causes and Outcomes of the Acute Chest Syndrome in Sickle Cell Disease. National Acute Chest Syndrome Study Group. The New England Journal of Medicine, 342, 1855-1865. https://doi.org/10.1056/NEJM200006223422502

[10] Castro, O., Brambilla, D.J., Thorington, B., Reindorf, C.A., Scott, R.B., Gillette, P., et al. (1994) The Acute Chest Syndrome in Sickle Cell Disease: Incidence and Risk Factors. The Cooperative Study of Sickle Cell Disease. Blood, 84, 643-649. https://doi.org/10.1182/blood.V84.2.643.643

[11] Bertholdt, S., Le, P.Q., Heijmans, C., Huybrechts, S., Dedeken, L., Devalck, C., et al. (2012) Les complications respiratoires de la drépanocytose chez les enfants: Le syndrome thoracique aigu. Revue Medicale de Bruxelles-Nouvelle Serie, 33, 138.

[12] Lewis, H.T.A.J. (2013) Drepanocytose: Complications medicales et chirurgicales en milieu pediatrique à 1 hopital national Donka. Gamal Abdel Nasser.

[13] Babela, J.R.M., Nzingoula, S. and Senga, P. (2005) Les crises vaso-occlusives drépanocytaires chez l'enfant et l'adolescent à Brazzaville, Congo. Étude rétrospective de 587 cas. Bull Soc PatholExot, 98, 365-370. 